\title{
Digital marketing communication in the age of globalization
}

\author{
Renáta Bílkovái,* \\ ${ }^{1}$ University of Pardubice, Faculty of Economics and Administration, Studentská 84, 53210 Pardubice, \\ Czech Republic
}

\begin{abstract}
Research background: The marketing perception has changed dramatically in recent years. Evolution of digital shopping and information technology generate new challenges. Internet marketing and social media have a significant impact on the behavior of consumers, and businesses are forced to look into new ways to play a role in each stage of the consumer's decision-making process. Nowadays marketing is concerned with understanding people's motivations and using these insights to create content and campaigns that engage and gain the attention of relevant users in the global Internet marketplace.

Purpose of the article: Consumers use different research strategies when preparing to purchase a product. The purpose of this article is to demonstrate the importance and relevance stages of the mapping customer decisionmaking process for better user experience and to segment users on the basis of their current intention to purchase goods.

Methods: The research work is based mainly on the STDC framework, which is used for strategic and content planning in order to adapt ads to the decision-making phase in which the customer is located. For the purposes of the article and to obtain target information, a quantitative self-service questionnaire was created. The purpose of this questionnaire was to find out the steps in the selection of specific goods and the factors that influenced their final purchase.

Findings \& Value added: The article has a practical focus on the recommendations for marketing communication which will attract more consumers and increase competitiveness, which is relevant especially in the context of globalization.
\end{abstract}

Keywords: marketing communication; digital marketing; content marketing; STDC framework

JEL Classification: $M 31 ; M 37 ; L 81$

\footnotetext{
* Corresponding author: renata.bilkova@upce.cz
} 


\section{Introduction}

Today's marketing world provides new opportunities to engage and attract the attention of relevant audiences. Online marketing has transformed marketing communication and the way how businesses communicate their brand. The customer journey has become one of the key concepts of marketing research (e.g. Becker and Jaakkola, 2020; Lemon and Verhoef, 2016). The customer's path is defined as a series of contact points in various marketing channels and media that customers go through before, during, and after a purchase (Kranzbuhler et al., 2018; Lemon and Verhoef, 2016; Patrício et al., 2011). Therefore, the emphasis on creating quality content is crucial and creates another way to gain customers.

Businesses gradually had to adapt to this digital age and translate their marketing strategies into a new modern form. Today, it is very important to follow new trends and techniques to attract, engage, and sell to the right audience. These new trends indicate the closest contact with the target segment of customers, and it is necessary to be with them online. As (Stankevich, 2017) states, this new approach is based on the premise that the customer is not only a source of immediate profit but is an opportunity for the long-term stability of the company. All this corresponds to the principle of innovative marketing thinking (Kotler, 2005), which requires the company or firm to constantly look for real improvements to its products and marketing. One of the possible innovations is the introduction and intensive use of digital technologies in marketing.

Digital marketing communication can be demarcated as a process of connecting businesses with people across online channels. The beginning of a digital communication strategy begins with determining what a company wants to achieve for its business. This goal can be to increase brand awareness, expand their reach, increase the number of potential customers or sales volume, build valuable relationships with their customers, and encourage customer loyalty.

The main difference between digital and traditional marketing communication is the medium through which the marketing message is transmitted. While traditional marketing uses traditional media such as print media, television, radio, or billboard advertising, digital marketing uses digital media such as social media, websites, e-mails, messaging applications, or blogs, and can use multiple types of multimedia media and interactivity to attract users. Digital marketing is evolving rapidly due to trends and new technologies, especially the use of the Internet and smartphones. According to (Statista, 2021), there are 4.66 billion active Internet users and 4.2 billion active social media users in the world. With such high numbers, the use of digital marketing and social networks offers great potential to reach customers. Several studies and statistics (Ahmedova, 2015; Forbes, 2018; Statista, 2021) show that the current most popular digital marketing channel among marketers is social media marketing. Using social media helps companies attract leads, promote brand awareness, and engage current customers. The success of the new generation of social media platforms has changed the way we socialize, interact, and shop. It has also brought new channels to digital marketing. Social media as a new marketing channel has been introduced in all sectors of the economy, including banks, trade, and services (Ahmedova, 2015).

Marketing deals with understanding people's motivations and using these insights to create campaigns that promote brands and encourage people to buy the products. It is a creative and often intuitive process. The purpose of this article is to demonstrate the importance of understanding customer behavior in their purchasing process. Customer journey mapping is a technique that allows professionals to better understand the customer experience at every stage a potential customer goes through before making a purchase. This knowledge enables retailers to better segment users based on their current intention to purchase and to create appropriate marketing strategies for a better user experience at each stage of their purchasing process and to support their loyalty for future purchases. 


\section{Research Methodology}

The customer experience is a dynamic process and usually displays the customer's journey as a series of touchpoints that customers interact with during the purchasing process. Customer experience is the combination of rational and emotional factors that influence customers' perceptions of a brand online (Chaffey and Chadwick, 2019). The customer journey consists of prepurchase, purchase, and post-purchase phases (Lemon and Verhoef, 2016).

Although many articles deal with consumer behavior and buying decision making, both academics and practitioners still question the best ways to model a consumer journey map. The growing focus on the customer experience is due to the fact that customers now communicate with companies through a variety of digital platforms, communications media, websites, pages, and engagement devices, resulting in more complex customer journeys. Companies are facing accelerating media and channel fragmentation, and new channel management has become the new standard (Brynjolfsson et al., 2013; Verhoef et al., 2004; Lemon and Verhoef, 2016). Understanding customer journeys is a prerequisite for developing superior customer experiences (Følstad and Kvale, 2018; Kuehnl et al., 2019).

Modeling customer journeys has one goal - to reach consumers at the moments that most influence their decisions when consumers are open to influence - touchpoints. Marketers are always looking for these moments and the factors that influence buying intention. Touchpoints are denoted through the marketing funnel for years (Figure 1). This traditional marketing funnel is also mentioned as the AIDA framework - Attention-Interest-DesireAction.

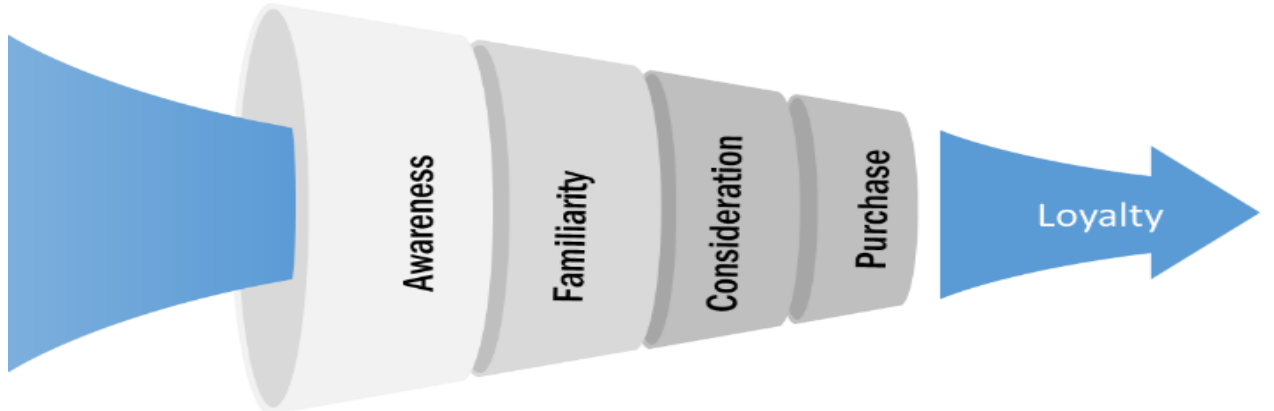

Figure 1. The Traditional marketing funnel.

Source: own

Although the AIDA model was designed in the last century, the basic principle of the model remains relevant despite various modifications. (Solomon, 2010) defined that the key to the successful implementation of the AIDA model is an understanding of the buyer's emotional motives. This framework focuses on the linear experience and reflects on the universal behavior of users (Siebert et al., 2020).

The rise of technology has made changes to the digital marketing funnel inevitable. Thanks to the globalization of information, users can search on the go, wherever they can find and buy products. They also have a huge amount of information available. Consumers can browse articles, read reviews on social networks, watch online videos, and more. All of these opportunities have allowed users to create their own, non-linear shopping experience. This evolution has led to the original funnel of online marketing becoming ineffective. Due to its structured and linear approach, it does not take into account the different journeys that the user can take, which means that companies are missing out on crucial opportunities to reach people and turn them into consumers. 
Today's digital marketing models try to demonstrate the non-linear path of customers, engaging the post-buying stage or loyalty. The fact that each user uses a different shopping behavior is affected by various factors, and this leads to other modern frameworks that map the customer's decision-making journey. Currently, McKinsey \& Company Loyalty Loop or STDC frameworks are the most mentioned among marketing practitioners.

Based on empirical research, in 2009, McKinsey \& Company suggested an alternative customer journey model that is represented as an endless loop (Figure 2), so the journey does not begin with the customer's perception of the brand and does not end with the purchase of a product. It continues as customers are engaged with the brand, learn more about products, accept products, become loyal to the brand, and will shop in the future (Hanlon, 2021). Creating a loyalty loop assumes that everyone is constantly considering, evaluating, and buying.

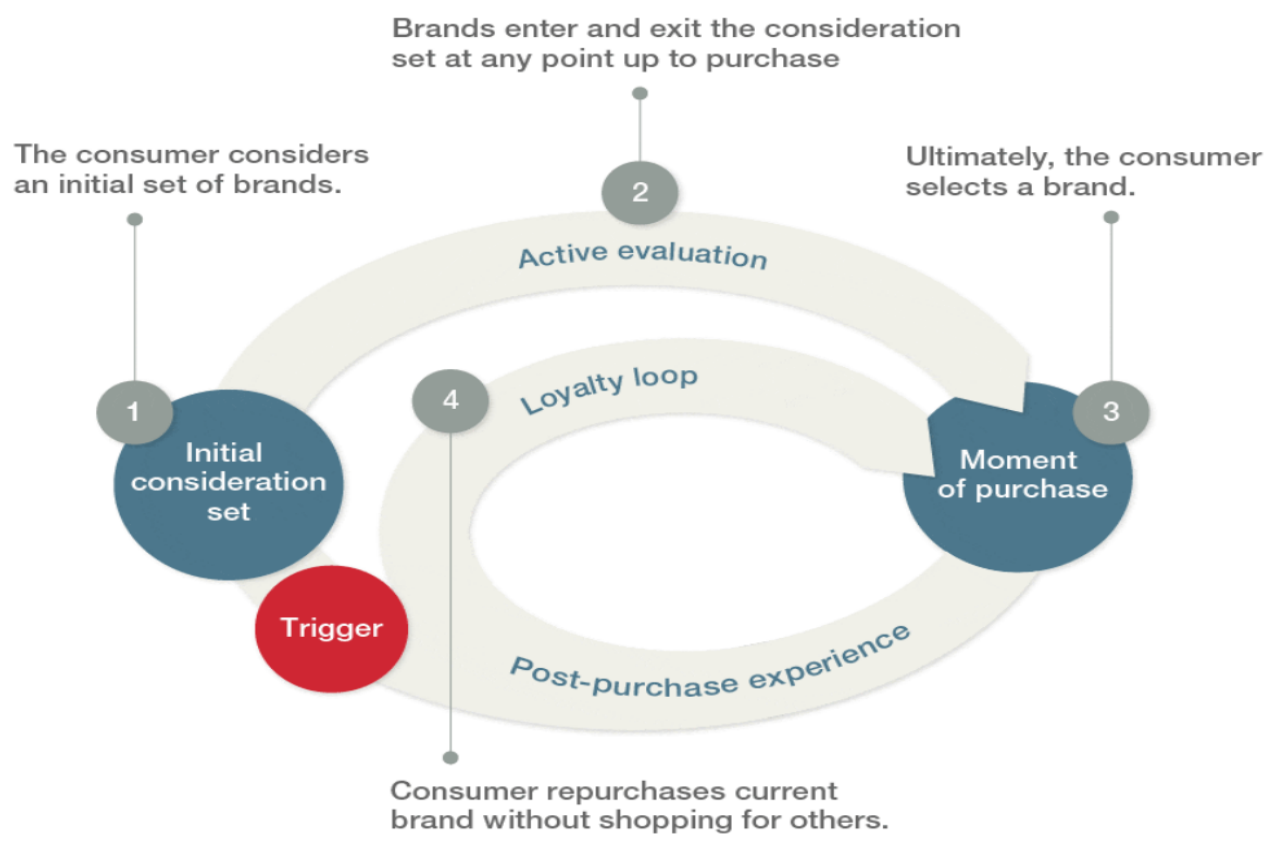

Figure 2. Loyalty loop consumer decision journey.

Source: McKinsey \& Company (2017)

The See-Think-Do-Care (STDC) framework is another modern approach to marketing strategy and content planning. The individual phases were named to encourage the intention to plan marketing campaigns from the customer's perspective. The author of the STDC concept is Avinash Kaushik, a Google executive and a global leader in marketing and analytics. The simplicity of this model lends itself to quick understanding and easy translation to diverse business situations, an essential attribute for any model's use and adoption (McTigue, 2019). The emphasis is on segmenting and targeting the specific audience according to the level of purchasing intention, in order to select appropriate marketing channels and adapt marketing communication to the decision-making phase of the buyer and recommends a different way of marketing communication across different platforms for a given phase (Figure 3). It is also a useful model to adopt in the context of a discussion of digital marketing analytics because, as it was specifically developed for digital marketing (Kaushik, 2013). 


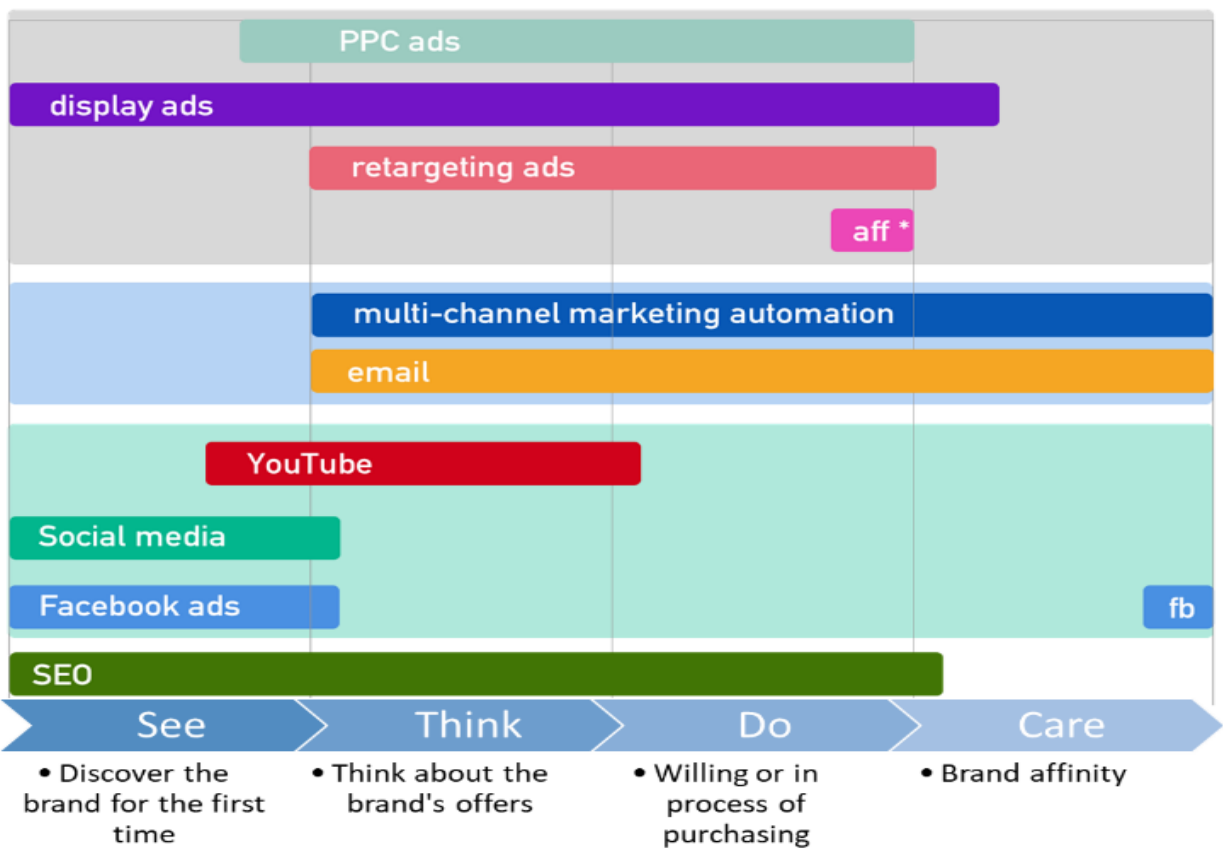

Figure 3. STDC Framework

Source: McTigue (2019)

The modern way of consumer decision-making means that marketing strategies, tactics, and measurements should be aligned with the needs and behavior of consumers at each stage of the decision-making journey, adapted to currently available technologies and the most used marketing channels, and also vary according to the type of company.

The main goal of this research is to identify suitable marketing channels and factors that will affect a selected group of customers in the final phases of purchase. Research results are based on a quantitative self-service questionnaire. The purpose of this questionnaire was to identify the steps in the selection of specific goods and the factors that influenced the final decision of the respondent in choosing a specified product.

\section{Results and Discussion}

The target group was a group of students from the University of Pardubice representing people from Generation X. This generation of young people aged 16-24 includes the majority of active customers shopping online (78\% of Internet users) (Eurostat, 2021). Today, it is crucial to consider the characteristics of this current young generation. They are a key audience on social media, tend to consume content on different platforms through different devices, and are usually very influenced by what their peers think. It is therefore important for traders to understand how this demographic group consumes information and, secondly, how to deliver the right marketing message that addresses them (Jílková et al., 2019).

The research is carried out on an ongoing basis and answers from 2016 and 2021 were selected to compare developments over time. This research focuses on consumer shopping behavior, specifically on factors and steps that influence customers' decision-making process. Research questions are: (1) What are the factors that affect the choice of e-shop? (2) Do these factors vary at different stages of the purchasing process? (3) Has there been a change in preferences over time? 
The research sample counts 331 respondents in 2016 (38\% of the respondents were men, $62 \%$ of the women) and 356 respondents in 2021 (44\% of the respondents were men, $56 \%$ of the women) in the age group $20-23$ years.

The questionnaire focused on general purchasing preferences when shopping online. First, the respondents had to state which criterion they considered the most important when choosing an e-shop (Figure 4).

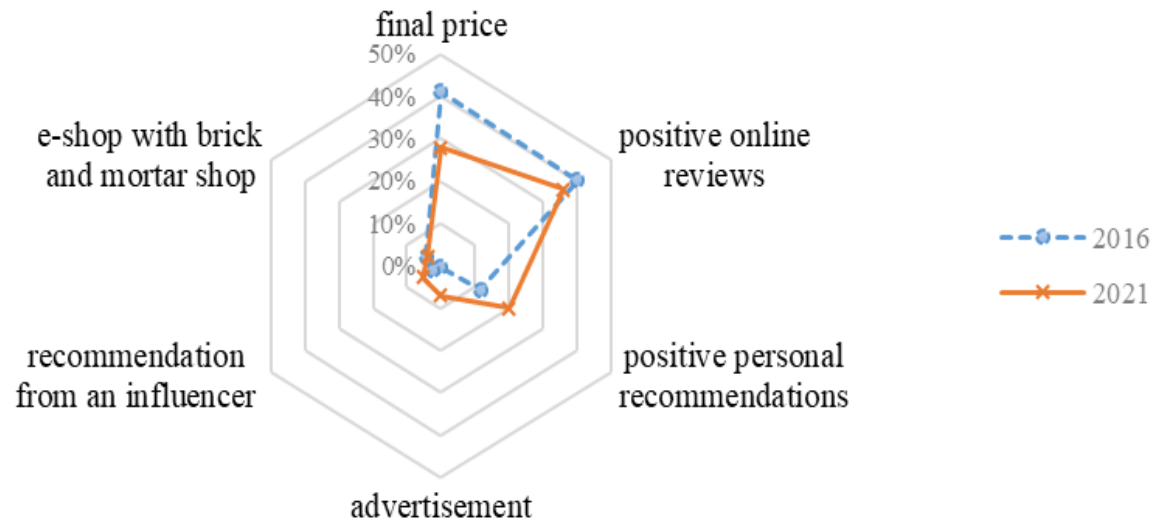

Figure 4. Comparison factors influencing the choice of the e-shop

Source: own research

The price is the most important criterion. It is not surprising because the better price is a general advantage of online shops (Pilík et al., 2017). Another significant criterion is a positive review of the e-shop and previous good experience with e-shop. Other factors received less than 3\% (Figure 5). However, in the last year, overall positive reviews on the web have come to the fore, followed by personal recommendations. The influence of social connections is growing.

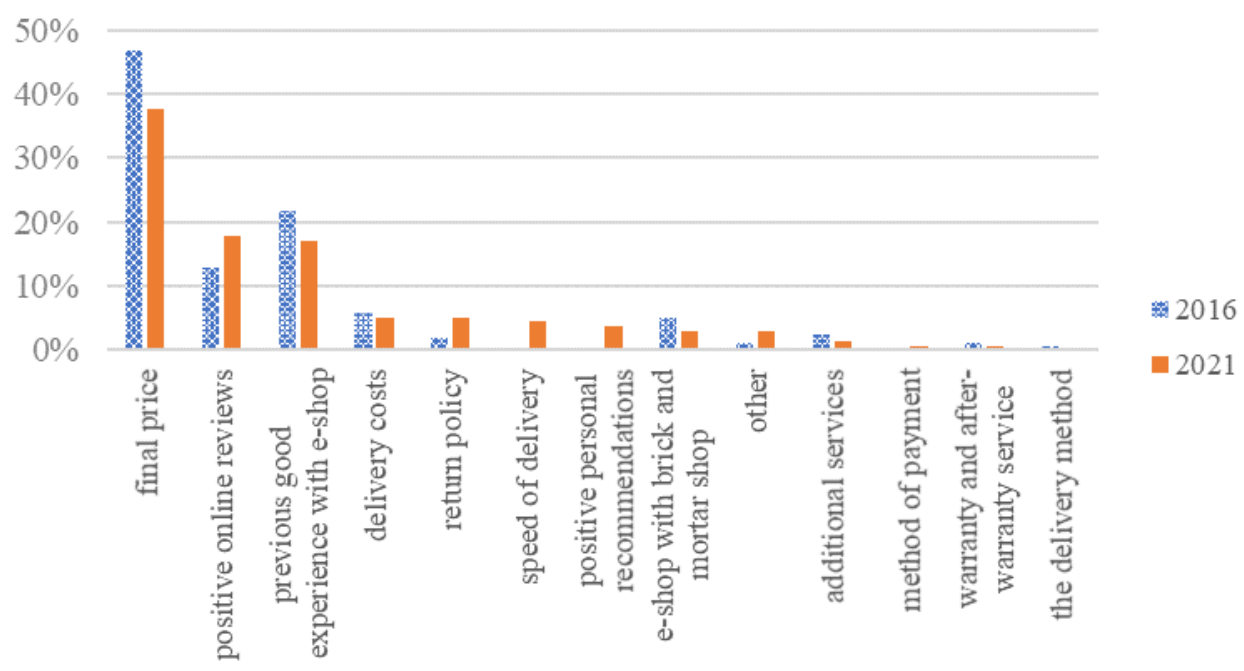

Figure 5. The list of factors influencing the choice of an e-shop 
Source: own research

The questionnaire also included practical questions, which included the task of describing the individual steps they go through when they are given the task of purchasing specific goods. In the first case, the assignment was indefinite (THINK phase from the STDC model) - buy some goods from the selected category. In the second case, respondents received a specific description of the goods, including the brand and type of goods (DO phase of the STDC model). The various steps that respondents could choose from included common online strategies, such as using search engines, visiting price comparison sites, as well as common offline strategies, such as visiting brick and mortar stores, viewing news and media ads, or discussing with friends or colleagues.

The results of the experiment with indefinite goods from the selected category and specific goods showed very similar results in terms of the steps of the final selection of the e-shop.

In the first step (Figure 6), respondents preferred to use a search engine. In 2015, price comparison sites (12\%) and the offline strategy - visit brick-and-mortar stores (17\%) had a decent percentage. In 2021, the decrease of these strategies can already be seen (price comparison sites $4 \%$, brick-and-mortar stores $10 \%$ ).

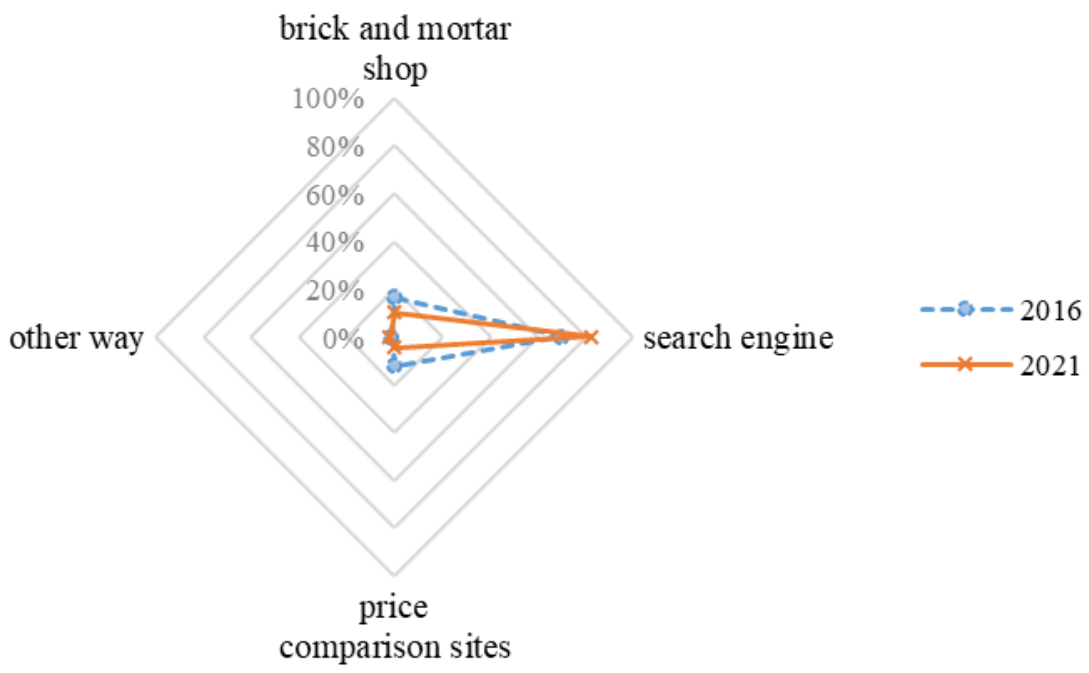

Figure 6. The first step in the strategy of searching an e-shop when purchasing a specified product

Source: own research

In the second step (Figure 7), respondents prefer to use a search engine. In 2015, price comparison sites (12\%) and the offline strategy - visit brick-and-mortar stores (17\%) had a decent percentage. In 2021, the decrease of these strategies can already be seen (price comparison sites $4 \%$, brick-and-mortar stores $10 \%$ ). 


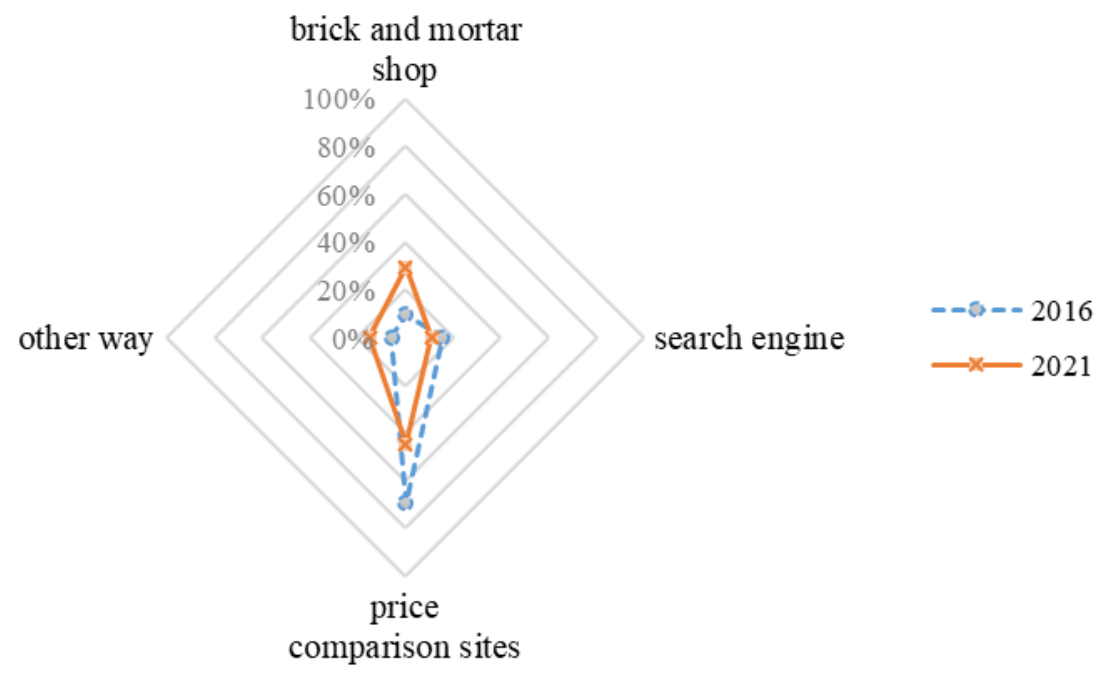

Figure 7. The second step in the strategy of searching an e-shop when purchasing a specified product Source: own research

In the second step (Figure 7), the decline in popularity of the use of price comparison sites is much better seen in the answers of the respondents. The reason for this decline remains a matter of discussion. Whether this decline is due to reduced confidence from previous experience with price comparison sites, an incomplete range of products for comparison, or generally declining confidence in the advertisement, to which we can include price comparators. Therefore, the topic for further research remains the importance and justification of the choice of individual criteria for channel selection in the selected phase of the customer's purchasing process.

\section{Conclusions}

Innovation in information technology is the main driver of globalization, and information technology has become a key part of the company's global business and marketing strategy. This article focused on clarifying the customer's shopping behavior when most people already are familiar with the online world and the possibilities of a global information connection. Technology improved, which means that customers had more places to buy their favorite products (online or offline). Many retailers quickly took advantage of this technology, increasing their chances of meeting customers.

As marketing evolves toward an increasingly digital future, it is becoming increasingly difficult to describe customer behavior in their decision-making process. Technologies and relevant marketing channels can change dynamically. The modern way consumers make decisions means that the choice of marketing strategy, tactics, selection of marketing channels, and measurement of conversions should not follow a universal model, but should be adapted to the type of company and the target audience. All of the suggested customer decision-making journey frameworks can help companies better understand how to create the survey of their target audiences and improve their marketing campaigns to reach consumers more effectively. 
The results of our questionnaire survey showed how important it is for the company to focus on the after-sales service phase - the CARE phase. A large number of respondents stated that an important factor is the recommendation of existing customers - satisfied customers become advocates of the company and thus bring the company more customers and sales.

\section{References}

1. Ahmedova, S. (2015). Factors for increasing the competitiveness of small and mediumsized enterprises (SMEs) in Bulgaria. Procedia-Social and Behavioral Sciences, 195, 1104-1112.

2. Becker, L., \& Jaakkola, E. (2020). Customer experience: fundamental premises and implications for research. Journal of the Academy of Marketing Science, 48, 630-648.

3. Brynjolfsson, E., Hu, Y. J., \& Rahman, M. S. (2013). Competing in the age of omnichannel retailing. MIT Sloan Management Review, 54(4), 23-29.

4. Chaffey, D., \& Ellis-Chadwick F. (2019). Digital Marketing: Strategy, Implementation and Practice. Seventh edition. Harlow, England: Pearson Education.

5. Eurostat. (2021, June 21). E-commerce statistics for individuals. https://ec.europa.eu/eurostat/statistics-explained/index.php?title=Ecommerce_statistics_for_individuals.

6. Følstad, A., \& Kvale, K. (2018). Customer journeys: A systematic literature review. Journal of Service Theory and Practice, 28(2), 196-227.

7. Forbes. (2018, March 9). The Advertising Conversion Rates For Every Major Tech. https://www.forbes.com/sites/priceonomics/2018/03/09/the-advertising-conversionrates-for-every-major-tech-platform.

8. Hanlon, A. (2021, July 22). Customer journey models to master your omnichannel strategy. $\quad$ https://www.smartinsights.com/marketing-planning/marketingmodels/mckinseys-consumer-decision-journey.

9. Jílková, P., \& Králová, P. (2019). Customer purchase behaviour and shopping in B2C ecommerce. International Scientific Conference Contemporary Issues in Business, Management and Economics Engineering.

10. Kaushik, A. (2015, July 6). See, think, do, care winning combo: Content +marketing +measurement!. https://www.kaushik.net/avinash/see-think-do-care-win-contentmarketing-measurement.

11. Kotler, P. (2005) Principles of Marketing. 4th European ed. Harlow: Prentice-Hall.

12. Kranzbuhler, A., Kleijnen, M.H.P., Morgan, R.E., \& Teerling, M. (2018). The multilevel nature of customer experience research: An integrative review and research agenda. International Journal of Management Reviews, 20, 433-456.

13. Kuehnl, C., Jozic, D., \& Homburg, C. (2019). Effective customer journey design: consumers'conception, measurement, and consequences, Journal of the Academy of Marketing Science, 47(3), 551-568.

14. Lemon, K. N., \& Verhoef, P. C. (2016). Understanding Customer Experience Throughout the Customer Journey. Journal of Marketing, 80(6), 69-96.

15. McKinsey \& Company. (2017, November 17). Ten years on the consumer decision journey: Where are we today? https://www.mckinsey.com/about-us/new-at-mckinseyblog/ten-years-on-the-consumer-decision-journey-where-are-we-today. 
16. McTigue, K. (2019). Leveraging touchpoints in today's branding environment. Kellogg on branding in a hyper-connected World, ed. A. Taybout and T. Calkins, 110-128. New York: Wiley.

17. Patrício, L., Fisk, R.P., Falcao e Cunha, J., \& Constantine, L. (2011). Multilevel service design: from customer value constellation to service experience blueprinting. Journal of Service Research, 14(2), 180-200.

18. Pilík, M., Juřičková, E., \& Kwarteng, M. A. (2017). On-line shopping behaviour in the Czech Republic under the digital transformation of economy. Economic Annals-XXI, (165), 119-123.

19. Siebert, A., Gopaldas, A., Lindridge, A., \& Simoes, C. (2020). Customer experience journeys: loyalty loops versus involvement spirals. Journal of Marketing, 84(4), 45-66.

20. Solomon, M. R. (2010). Consumer behavior: A European perspective. Harlow (UK): Pearson Education Limited.

21. Stankevich, A. (2017). Explaining the consumer decision-making process: Critical literature review. Journal of International Business Research and Marketing, 2(6).

22. Statista. (2021, September 10). Global digital population as of January 2021. https://www.statista.com/statistics/617136/digital-population-worldwide.

23. Verhoef, P. C., Antonides, G., \& de Hoog, A. N. (2004). Service Encounters as a Sequence of Events the Importance of Peak Experiences. Journal of Service Research, 7(1), 53-64. 